\title{
The Deception of the Wise Woman of Tekoa
}

\subsubsection{Samuel 14:1-3}

At the lower level of 14:1 Joab is apparently aware that David is thinking of Absalom. (I return to the precise interpretation of this claim below). In 14:2 Joab sends for a wise woman of Tekoa and commands her to pretend that she is a mourner, and in 14:3 Joab tells the woman what to say to David. At the upper level of the narrative the ironist insinuates that David is about to be fooled once again. David has already been deceived by Amnon (2 Sam. 13:1-7) and Absalom (2 Sam. 13:24-27). In both of these instances, ironically, David, the supposedly wise king, was easily fooled by a subordinate. Moreover, he was spoken of in a ridiculing manner because he was fooled easily. Further, David was the unknowing victim of the irony. Now there is a further contrast. This time the contrast is between David and Joab. For Joab is about to fool David. This contrast is emphasised by the use of incongruous language, especially in the context of our background knowledge that David has been fooled by Amnon etc. The incongruous language is particularly notable in the pattern of verbose language immediately followed by curt language. The verbose language in 14:1-3a (the detail of the ruse) is followed by the curt statement in 14:3b that Joab put the words into the woman's mouth. This incongruity emphasizes Joab's action or, to be more specific, that David was about to be tricked by his subordinate, Joab, the general of his army.

The grade of verbal irony is covert as it is implied by means of the language used and our background knowledge. Indeed, some of this background knowledge is actually alluded to in 14:1-3. Notably, the narrative in 14:1-3 alludes to the narrative in 13:3-5. In 13:3-5 Jonadab and Amnon conspire to trick David. כhus, in 14:1 Joab perceives that the king is thinking of Absalom: כי־לב המלך בעל־אבשלום 13:4 where Jonadab notices that something is troubling Amnon.

1 "Now Joab the son of Zeruial perceived that the king was thinking of Absalom". Author's translation. 
In 14:2 we are introduced to the אשה חכם from Tekoa who will pretend to be a mourner. This alludes to 13:3 in which Jonadab is described as being a who persuades Amnon to pretend to be sick (13:3-5).

The parallels that I have just drawn between 14:1-3 and 13:3-5 may suggest that the correct interpretation of על (14:1) is that David was thinking of Absalom. Other scholars have argued that the preposition על, in this context, means that David longed for Absalom, ${ }^{4}$ that David's thoughts were against Absalom, ${ }^{5}$ or that David was thinking of Absalom. ${ }^{6}$ At this stage in the narrative there is not enough background knowledge to provide a definitive interpretation of David's intentions. However, as argued, the episode in 14:1-3 parallels events in 13:3-5. These parallels support McCarter's suggestion that the preposition על indicates that the king was thinking of Absalom; thereby, creating an opening in the narrative for Joab to put forth his plan to ensure that David permits Absalom to return to Jerusalem. ${ }^{7}$ This mirrors 13:4 in particular, where Jonadab is aware of Amnon appearing to be troubled thereby creating an opening for Jonadab to put forth his plan to Amnon.

In summation, 14:1-3 alludes to $13: 3-5$ and, thereby, adds weight to the ironist's implied pejorative criticism of David, namely, that he is foolish because he is easily deceived. The sub-category of impersonal irony, in this instance, is insinuation.

\subsubsection{Samuel 14:4-7}

The narrative in 14:4-7 is not an instance of irony by analogy as is found in Nathan's Parable ${ }^{8}$ (2 Sam. 12:1-6) but instead involves a deception, not unlike

2 "Wise woman".

3 "Wise man".

4 Jacob Hoftijzer, "David and the Tekoite woman," VT 20, no. 4 (1970), 419-444, 419.

5 Anderson argues that it is most likely that David was hostile towards Absalom, not only for the presence of על but also because it was necessary for Joab to persuade David to allow Absalom to return to Jerusalem. (Anderson, WBC, Vol. 11. 2 Samuel, 187). Fokkelman argues that it is improbable to assume that David longed for Absalom given the length of time that David refused to see Absalom (14:24, 28), and in the manner in which David accepts the oath (14:21), but then bans Absalom from his presence (14:24). The whole ruse might also seem unnecessary if David truly longed for Absalom. Instead, Fokkelman suggests that this sentence would be better read that David longed to march out against Absalom, as David mourned for Amnon (Fokkelman, "King David (II Sam. 9-20 \& I Kgs. 1-2)," 126-127).

6 McCarter suggests that this sentence does not indicate the nature of David's thoughts, but rather the idea that David was thinking of Absalom, which meant that it was an opportune time for Joab to enact his plan. (McCarter Jr., II Samuel, 344).

7 Ibid.

8 Hugh Pyper's suggestion that this story is a parody of Nathan's Parable must be investigated further. Parody is ordinarily employed to ridicule an original document (Muecke, The 
the cases which are spoken of in 2 Samuel 13:1-7 and 24-27. Similarly, in 14:47, David is tricked into making a poor decision, is the object of ironic attack and is the unknowing victim of the irony. The ironist's device in this case is the pretended defence of the victim, as it was in 2 Samuel 13:1-7; 24-27. Of particular note, is the similarity of this episode where David is tricked by the 'wise woman of Tekoa,' with 13:3 where David is tricked, in essence, by Amnon's 'wise' friend Jonadab. The contrast here is between the cunning of the wise woman of Tekoa and the foolishness of David. This contrast sets up the ironic content for the pretended defence of the victim. Thus, the ironist pretends to be defending David against the crafty woman of Tekoa. However, David is actually the object of ironic attack since a reasonable person would have seen through the 'wise' woman's ruse.

At the lower level of 14:4-7 the wise woman of Tekoa acts out her part in Joab's ruse. In 14:4 she does obeisance to David. David asks her what is troubling her, and she tells him that she is a widow (14:5) and that she had two sons who were playing in the field when one struck the other and killed him (14:6). In 14:7 the woman tells David that the entire family were inflamed by the killing and wanted to kill her son in revenge, even though he was her only remaining son. The woman tells David that this act would leave her husband without an heir.

The situation outlined by the woman is obviously analogous to David's, indeed deliberately so. Therefore, David should have been suspicious. Ironically, however, David — who as king is supposed to be wise-is confidently oblivious to the deception, and, hence, is the unknowing victim of irony. (Note that this is not an instance of irony by analogy since the analogy is merely in the service of the deception). ${ }^{9}$ The incongruity in the narrative is the fact that the King

Compass of Irony 78). In the usual use of parody the story of the woman of Tekoa would be used to poke fun of Nathan's Parable. This is inconsistent with the narrative, given that Nathan's Parable highlights the criticism of David (2 Sam. 12:7-14). It would, thereby, seem incongruent that the narrative would make fun of God's judgement that David has violated laws by taking Bathsheba and having her husband killed. However, Pyper argues that a parody of Nathan's Parable draws the reader's attention to the message in the original document (Pyper, "The Enticement to Re-read Repetition as Parody in 2 Samuel," BiblInt 1, no. 2 (1993), $\left.153^{-165}, 161\right)$. This argument is consistent with the narrative, however, it is not the common use of parody. Pyper argues that the parodying features in the opening verses of chapter 14 are as follows; the substitution of Joab for God (14:1), the substitution of a woman for a prophet (14:2), and the account of a woman as (given the historical context) (14:2) (Pyper, "The Enticement to Re-Read Repetition as Parody in 2 Samuel," 157). These features are also common to the sub-category of pretended defence of the victim.

9 Note in irony by analogy, the analogous story is used to criticize the original story. Muecke, The Compass of Irony, $7^{0}-71$. 
of Israel is foolish and the lowly woman of Tekoa wise. The grade of irony is covert, as the irony is not immediately apparent, and is only apprehended with knowledge of the background story of David and his sons.

In the story of the woman of Tekoa, David would seem to be analogous to the woman of Tekoa, and the sons who fought in the field appear to be analogous to Absalom and Amnon. Yet, there are some striking differences between the story of the woman of Tekoa and David's own situation. These differences ultimately obstruct a correct judgment by David in respect of Absalom's punishment notwithstanding that a correct judgment by David in this matter appears to be both the woman's and Joab's goal.

In this respect the woman of Tekoa's story contrasts with Nathan's Parable. In Nathan's Parable, you will recall, a parallel is drawn between the rich man's mistreatment of the poor man and David's mistreatment of Uriah. Of course, as discussed, there are differences between the story of the rich man and the story of David and Bathsheba. For instance, in the story of the rich man there is a traveller whereas there is no traveller in the story of David and Bathsheba. However, as we saw in the discussion in 2 Samuel 12:1-6, these differences do not obstruct David in making a correct judgement in respect of his sin of 'stealing' someone else's wife (Bathsheba) as a result of seeing the analogy between his 'theft' of Bathsheba and the rich man's theft of the lamb from the poor man. By contrast, there are important differences between the woman of Tekoa's story and David's circumstances vis-à-vis Absalom such that these differences are likely to obstruct David in making a correct judgment in respect of Absalom's punishment.

In the story of the woman of Tekoa, the woman of Tekoa only had two sons (14:7), whereas David had many sons. This is significant, as the woman of Tekoa would, potentially, lose the sole heir to her husband's inheritance (14:7). This would not be the case for David. Moreover, the woman was a widow (14:6), whereas David was not. This is particularly pertinent given that an אלמנה was a woman who did not have a male within a broader kingroup to look after her. This meant that an אלמנה was one of the most vulnerable people of the community. ${ }^{10}$ David was the most powerful man in Israel. Given these differences between the story of the woman of Tekoa and David's situation the judgement to be made in the case of her son is quite different from the judgment to be made in the case of Absalom. In other words, the analogy being drawn between the woman of Tekoa's story and David's situation is likely to obstruct David's correct judgement in respect of Absalom.

10 John Rook, "When is a Widow Not a Widow? Guardianship Provides an Answer," Biblical Theology Bulletin:Journal of Bible and Culture, 28, no. 1 (1998), 4-6, 5 . 
Therefore, the story of the woman of Tekoa should not be considered to be analogous to Nathan's Parable. Rather the story of the woman of Tekoa should be regarded as analogous to other instances of deception in the narrative, such as Jonadab and Amnon's deception of David, and Absalom's deception of David.

Other significant differences between Nathan's Parable and the story of the woman of Tekoa include the following. In Nathan's Parable, God was known to be the architect of the Parable. In the case of the story of the woman of Tekoa, Joab was the author of the story and the story was a complete fabrication intended to deceive David. In Nathan's Parable the agent who delivers the Parable is a prophet, whereas, in the story of the woman of Tekoa, the agent is an actress. Furthermore, the episode in Nathan's Parable can be considered irony by analogy as it seeks to criticize the analogous situation (David's situation vis-a-via Bathsheba), and to bring David to an awareness of his unlawful actions in respect of Bathsheba through a process of self-judgement. In the story of the woman of Tekoa, as in the case of the other deceptions mentioned, the deceivers (Joab and the woman of Tekoa) use deception to manipulate the king in the service of ends other than his making correct judgments.

Further, the other episodes of deception have had disastrous outcomes. For instance, Amnon's deception leads to a rape and ultimately ends in his own death. Absalom's deception leads to the murder of his brother and, ultimately, exile for him. In the next section, I argue that the desired outcome of Joab's ruse (Absalom's return to Jerusalem) is unlawful and potentially disastrous.

Notwithstanding what I have argued thus far, the ruse of the woman of Tekoa does resemble the story of Nathan's Parable in one significant yet less obvious respect (leaving aside the obvious similarities), that being, it alludes to a previous story. In Nathan's Parable the story of David and Nabal (1 Sam. 25) is alluded to (and utilised) and in the story of the woman of Tekoa, the story of Cain and Abel is alluded to. However, in the case of Nathan's Parable, the analogy to David and Nabal is (as we have seen) helpful, whereas, in the story of the woman of Tekoa, the analogy to the story of Cain and Abel is unhelpful. For the story of Cain and Abel involves a reduced punishment for Cain whereas the woman of Tekoa is requesting no punishment for her son and, likewise, Joab and the woman of Tekoa are seeking to cause David to permit Absalom to go without any punishment.

I now argue that it would have been inconsistent both with God's law and with the rules of blood vengeance for David not to punish Absalom for killing Amnon. To facilitate the argument, I provide a comparison between the story of the woman of Tekoa, David's situation vis-à-vis Absalom, and the story of Cain and Abel. The story of Cain and Abel is relevant because it functions as 
a quasi-legal precedent in a context in which the application of God's law and the rules of blood vengeance are otherwise unclear. In 14:6 the woman of Tekoa tells David that she had two sons and one of the sons killed the other son in a שדהה. In the story of Absalom and Amnon, Absalom orders Amnon's execution $(13: 28)$. In the story of the brothers Cain and Abel, Cain lured Abel out into a שדה and killed him (Gen 4:8). In 14:7 (in overstated language) the woman tells David that all of the clan have risen up against her, as they wish to kill her son to avenge a murder he has committed. The clan are prepared to kill her son even though he is an heir. This would eliminate the woman's husband's line (14:7).

In 14:7 the wording ונשמידה גם את־היורש (... and we will detroy the heir also) in the women's story suggests that the clan are trying to kill the son in order to take the inheritance, ${ }^{11}$ and not necessarily on the basis of their morally motivated judgement. This is not in keeping with the rules of blood vengeance which require an appropriate punishment for a crime (Deut. 19:6). In the example of the ruse, the blood avenger it is not within his rights to kill the woman of Tekoa's son in order to benefit from the inheritance. Similarly, Absalom's hatred was the motivation for Amnon's murder. This is not in keeping with the rules of blood vengeance. These rules limit violence and prohibit retaliation driven by unfettered rage. ${ }^{12}$ However, in 14:7 there is no explicit statement that David's clan are planning to kill Absalom in order to take his inheritance. Indeed, Absalom's death may be warranted, even if this means that the clan must kill one of its own, because the preservation of the clan is contingent upon protecting itself from internal threats. So, while there are some similarities between the situation of the woman of Tekoa's son and Absalom there are important differences, including some additional to the ones already mentioned.

The outcome of the story of Cain and Abel is that God punishes Cain (Gen. 4:12) by sending him into exile rather than by killing him. Moreover, God protects Cain by way of the mark of Cain (Gen. 4:15). Notably, Cain is the only remaining son of the original human beings. Hence it is crucial to protect Cain. Likewise, Absalom flees to Geshur (2 Sam. 13:37) and is in exile. Absalom does not have the protection that Cain had but, crucially, he is not the only

11 It is possible that Joab, who created the ruse, believed that Absalom killed Amnon in order to take his inheritance. This is not the case as Absalom killed Amnon out of hatred because Amnon raped Tamar (2 Sam. 13:22, 32). However, as Absalom told Tamar not to mention the rape (2 Sam. 13:20) it is possible that Joab would not know this. The confusion adds to the comedy of events.

12 Pamela Barmash, Homicide in the Biblical World (Cambridge: Cambridge University Press, 2005), 24. 
remaining son of David, let alone of the human race. The situation of the remaining son of the woman of Tekoa is somewhat similar to that of Cain, although obviously his death would be far less significant.

So, in the case of the woman from Tekoa it may be valid to protect her last remaining son; moreover, the intentions of the blood-avenger are corrupt, and the clan would be damaged by killing her son. In the case of Absalom, there are other sons. Moreover, the blood-avenger's motives (assuming that there is a blood-avenger who seeks vengeance for Amnon's murder) are correct. Furthermore, Absalom's killing of Amnon was unlawful in that he did not have the support of other family members; rather Absalom had to trick David into allowing Amnon to go to the sheep-shearing festival where he was killed (2 Sam. 13:26-27). Therefore, the clan would be protected from not having Absalom in the family, given his propensity to engage in unlawful killing motivated by brooding anger (2 Sam. 13:22). In conclusion, while there are similarities between all three stories, each story is different from the other two in some important respects. Therefore, the story of Cain and Abel cannot be used to determine the appropriate punishment for Absalom. Nor can the woman of Tekoa's story be so used.

\subsubsection{Samuel 14:8-11}

At the lower level of 14:8 David tells the woman of Tekoa to go home, and that he will give orders concerning her situation. In 14:9 the woman says to David "On me be the guilt, my lord, the king, and on my father's house; let the king and his house be guiltless" (14: 9). David tells the woman he will protect her (14:10). The woman implores David "to keep the Lord your God in mind" (14:10) so that the blood-redeemer will not kill her son. David assures her that her son will be safe (14:11). ${ }^{13}$ At the upper level of the narrative the implication is that David has made an oath to protect her son. Moreover, the ironist implies, by way of analogy (but not irony by analogy), that David will 'take on the guilt' in the case of the decision concerning the fate of Absalom. ${ }^{14}$

13 Note the additional irony in David's statement in 14:11. In this verse David tells the woman of Tekoa that not a hair of her son's head will fall to the ground. This is ironic given that Absalom, David's son, eventually did die by his hair being entangled in a tree so that he literally did not fall to the ground. For this observation I am indebted to David Marcus' comments on my PhD thesis.

14 When the woman of Tekoa says that she will 'take on the guilt' of the decision that David makes in respect of the fate of her son, she is being utterly insincere; after all, the entire episode about an alleged son is a fabrication. On the other hand, the woman of Tekoa actually does desire David to 'Take on the guilt' in relation to Absalom, albeit she does not communicate this desire of hers to David. At any rate, the implication is that the woman of Tekoa believes that the analogy between the story about her son and the situation of 
The grade of verbal irony is covert, as it is not immediately apparent. However, the irony is highlighted by the exaggerated language. This suggests that the mode of verbal irony is impersonal irony and the sub-category is overstatement. For instance, David commands the woman to go to her house while he considers her request in 14:8. Yet, instead of following David's orders, the woman makes a dramatic, overstated declaration that she will take on the guilt of David's decision, so that the royal house will remain guiltless (14:9):

עלי אדני המלך העון ועל־בית אבי והמלך וכסאו נקי

(On me be the guilt, my lord the king, and on my father's house; let the king and his throne be guiltless). ${ }^{15}$

This comment is unclear. It may be the case that the woman has given her assurance to David that she will bear the guilt if the king's judgement proves to be in error, ${ }^{16}$ it may express the formal language which was used in the court; ${ }^{17}$ or it may be an extra plea for forgiveness. ${ }^{18}$ However, regardless of the intention of the statement, the remark is overstated. Schulz likens this remark to Abigail's speech to David (1 Sam. 25:31) which he argues is also illogical, gushing, and calculating. ${ }^{19}$

The implications of the overstated language are best considered within the framework of the previous section. If the story of the woman of Tekoa involves an allusion to David, then it is possible that the woman's comment that she will take on the guilt implies that David should take on the guilt of Absalom. Schulz explains this in detail below.

The woman's offer to assume the bloodguilt of her son is ultimately paradoxical. "Let the sin be upon me, my lord the king, and on my father's house; the king and his throne shall be clear" (14:9) sounds generous, until we consider that in the parable the woman is the king. David, in other words, will incur bloodguilt if Absalom is allowed to live. Such a stain according to Gen 9:5-6; Exod 21:12; Lev 24:17; Num 35:16-21, 31; Deut

Absalom is sufficiently clear that David will ultimately see it and accept that that his adjudication in the case of Absalom ought to be same as in the case of her son.

15 Translation from the Rsv.

16 Anderson, WBC, Vol. 11. 2 Samuel, 188.

17 K. N. Jung, Court Etiquette in the Old Testament. Drew University: Ph.D. dissertation, 1979, $42-52$.

18 Jacob Hoftijzer, "David and the Tekoite Woman," VT 20 (1970), 419-444, 427.

19 Schulz, "Narrative Art in the Books of Samuel," 137-138. 
19:11-13, can be dissipated only by blood, not by forgiveness. Again, the message is that David must kill Absalom to eliminate bloodguilt. ${ }^{20}$

According to Schulz's assessment of the analogies, if David takes on the bloodguilt of Absalom then the message is that David should die instead of Absalom. However, as has been mentioned previously, it cannot be certain that the allusion to David is intended; perhaps the speech of the woman of Tekoa is overstated but without this intention (14:9).

In the next step in the narrative David reassures the woman that he will keep her free from any harassment (14:10). It is only in 14:11 when the woman asks David to ensure that the blood avenger does not destroy her son, that David responds with, what Alter calls the "hyperbolic declaration."21 David's response is not only an overstated declaration, it also signifies a significant development in the narrative. For the mention of Yahweh implies that David spoke an oath in God's name. ${ }^{22}$ Thereby, David is tricked into taking on Absalom's bloodguilt by the lowly figure of the woman of Tekoa. ${ }^{23}$

Ironically, David has now solemnly committed himself to protect 'someone' from a non-existent threat in a non-existent situation. Moreover, given the differences between the circumstance of Absalom and that of the woman of Tekoa's son (differences elaborated above), David has been tricked into making an adjudication in the case of Absalom based on an erroneous comparison between Absalom's circumstance and that of the woman of Tekoa's son. Moreover, in doing so he has 'taken on the guilt' of his decision in respect of Absalom with the possible consequence that David himself might need to be killed.

The opposition in the narrative is between what is said and what is meant. The woman says that she will 'take on the guilt' of the decision in the case of her son, however, the implication is that David will take on the guilt of the decision in the case of Absalom. David is the object of ironic attack, and the unknowing victim of irony.

\footnotetext{
$20 \quad$ Ibid., $5^{2}$.

21 Robert Alter, The David Story, 277.

22 Hoftijzer, "David and the Tekoite Woman," 428 n.1

23 In addition to the argument that this narrative is a parody, it has also been suggested that this narrative is a 'juridical parable.' The essence of the juridical parable is that it concerns a legal issue and a judge making a self-judgement (Simon, 207-242). The problem with this assessment, as Gunn argues, is that it presupposes the legitimacy of a litigant putting their case to a king or a judge in the dock. (Gunn, The Story of King David. Genre and Interpretation, 41-42).
} 


\subsubsection{Samuel 14:12-14}

At the lower level of 14:12 the woman of Tekoa asks David for permission to speak to him. In 14:13 the woman of Tekoa tells David that in giving his decision with respect to her son he has, in effect, convicted himself if he does not bring Absalom back to Jerusalem. She also asks David, "Why then have you reckoned such a thing against the people of God?"24 (14:13). This is a rhetorical question. At the lower (explicit) level it is a straightforward question and the assumption is that the woman of Tekoa is waiting for a response from David; instead she continues her argument in the speech. Being a rhetorical question, there is an implication and an opposition between what is said and what is meant. In asking this particular rhetorical question she is, in effect, implying that David does not administer justice impartially. Therefore, David is the object of the ironic attack. The grade of verbal irony is overt, as it is immediately apparent.

The woman's reproachful rhetorical question (and expansion thereof) is not unlike the reproachful rhetorical question (and expansions thereof) of Uriah (2 Sam. 11:11). However, in the cases of Uriah, it is clear that he was fighting an injustice and imploring righteous behaviour. In the case of the woman of Tekoa, this conclusion cannot be established. There is a debate regarding whether David should have allowed Absalom to be killed or left in exile. ${ }^{25}$ Propp suggests that the very nature of the parable, which associates Absalom with the murderous son of the woman of Tekoa, convincingly indicts Absalom as a murderer. ${ }^{26}$ Indeed, Propp argues that the proper course of action to take in regards to Absalom is to kill him and that this course of action is in line with retributive justice. ${ }^{27}$

In terms of the legal texts Genesis 9:5-6; Exodus 21:12; Leviticus 24:17; Numbers 35:16-21, 31; Deuteronomy 19:11-13 the right course of action is to kill Absalom, as he lay in wait to kill Amnon out of anger (2 Sam. 22-23). However, the woman of Tekoa appears to be asking the king for mercy for Absalom (as well as (explicitly) for her son). This implicit request is made by means of

\footnotetext{
24 Author's translation.

25 Anderson argues that the woman's parable serves as an apologia for David, as the rightful course of action for David would have been to leave Absalom in exile. Thereby, the knowledge that David was tricked into allowing Absalom to leave exile exonerates David of not rightfully following the law. However, the knowledge that David can be easily manipulated does not inspire confidence in the king, therefore, the suggestion that there is irony in this passage is preferable (Anderson, WBC, Vol. 11. 2 Samuel, 186).

26 Propp, "David and the Tekoite Woman," 50.

27 Ibid., 51.
} 
an allusion to the story of Cain and Abel, ${ }^{28}$ where God is merciful to Cain. Therefore, it is necessary to revisit our commentary on the story of Cain and Abel in order to determine the proper punishment for Absalom.

The outcome of the story of Cain and Abel is that God punishes Cain (Gen. 4:12). However, God also protects Cain (Gen. 4:15). In the case of Absalom, it may be argued that his state in exile is not unlike Cain's situation. Both men should have received the punishment of death, however, instead they are exiled. ${ }^{29}$ God's mercy in the story of Cain and Abel consists in a reduction of punishment. The woman of Tekoa requests that David do away completely with any punishment for Absalom. One difficulty with this request is that David is being asked not to punish Absalom, yet Absalom has committed the serious crime of murder. A second difficulty is that David is himself implicated in this crime since it was David's decision not to punish Amnon which caused Absalom to kill Amnon (2 Sam. 13:21-22). A third difficulty is that God did not lift his punishment from David (2 Sam. 12:10-14) when David implored God to let the child from his illegitimate union live (2 Sam. 12:22). Thereby, although God is merciful, God still punishes both David and Cain. Surely David should act as God did.

It may also be suggested that only God had the authority to reduce Cain's punishment and, therefore, only God — and not David—has the authority to reduce Absalom's. In response it might be said that in swearing חייהוה David swears an oath to protect the woman's son, and (according to the woman of Tekoa) on pain of inconsistency Absalom also (14:12). ${ }^{30}$ However, we have pointed to important differences in the two cases; so arguably David ought not to swear to protect Absalom even if it is reasonable for him to swear to protect the woman of Tekoa's son.

In conclusion, we saw above that David was the object of the woman of Tekoa's ironic attack (by means of her rhetorical question). However, ironically, it is the inadequacies of the woman of Tekoa's analogy and perspective that have now been revealed. Therefore, the ironist (the woman of Tekoa) has herself become the object of irony. Moreover, she is evidently confidently unaware of this. Therefore, she is also the victim of irony.

28 J. Blenkinsopp, “Jonathan's Sacrilege. 1 SM 14, 1-46: A Study in Literary History," $C B Q, 6$ (1964), 423-49, 449 .

29 J. L. Jensen's suggestion that Absalom is "less guilty" as he did not kill Amnon with his own hands has merit. "Desire, Rivalry and Collective Violence in the "Succession Narrative," JSOT 55 (1992), 39-59, 54 .

$30 \quad$ McCarter Jr., II Samuel, 348. 


\subsubsection{Samuel 14:15-17}

At the lower level of 14:15 the woman of Tekoa tells David that she has come to tell David these things, as the people have made her afraid, and because she believes that David will grant her request. At the lower level of 14:16 the woman suggests to David that he protect her and her son from the blood-avenger. In 14:17 the woman tells David that his word will set her at peace, as the king's judgement is like the lord's, and that David's word is like the angel of God, which discerns "good and evil." At the upper level of the narrative the ironist implies that David is not a good administrator of justice. The opposition in the narrative concerns the difference between what is said and what is implied. David is the object of ironic attack, and the unknowing victim of the irony.

The grade of verbal irony is covert, as it is not immediately apparent. The mode of irony is impersonal, and the sub-category of impersonal irony is praise in order to blame. This sub-category of irony praises the object of ironic attack for qualities which are known to be lacking. ${ }^{32}$

31 There is a discussion regarding the ordering of the woman's speech. Most scholars tend to agree with Cook that the true order of this chapter is as follows: 13:38-14:7, 15-17, 8-14, 1833. In this ordering of events the king gives his orders and the woman responds to those commands (14:8-14) at the completion of the woman's plea ("Notes on the Composition of 2 Samuel," AJSL, XVI (1899-1900), 145-177, 158). On the other hand Ridout (137) argues that the woman of Tekoa reverts back to her plea in verse 14:15 in order to divert David's attention from Joab's role in the drama. The verses in the story of the woman from Tekoa do appear to be presented in a disjointed order, and redaction criticism may alleviate this clumsiness. However, in an ironic interpretation this clumsiness may go towards indicating that the woman of Tekoa is not such a smooth operator. This presentation of the woman of Tekoa is important when we understand the analogy in comparison with Nathan's Parable (12:1-15). The distinction of a prophet speaking God's judgement must be described with distinction from the trickery of a human agent. If this narrative is compared with the story of Jonadab and Amnon, it can be noted that there is a similar pattern of repetition in the outworking of the plan (13:5-6). Similarly, Absalom's plan to invite Amnon to the sheep shearing festival is not without a degree of persuasion (13:23-27). This technique of repetition not only adds suspense to the story, but also emphasizes the strength of the deception. Ridout (137) suggests that the 'wise' advice of Jonadab and the woman of Tekoa ends in unmitigated disaster indicating an irony (Ridout, "Prose Composition Techniques in the Succession Narrative (2 Sam 7, 9-20; 1 Kgs $1-2)$ ). Rendsburg argues that "disordered speech and storytelling" is not uncommon in biblical stories and cites the following examples: Gen 37:28, 30; Ruth 2:7, Judg 18:14-20, 1 Sam 9:12-13, 1 Sam 17:38. G. A. Rendsburg, "Confused language as a Deliberate Literary Device in Biblical Hebrew Narrative," JHScr 2.6 (1999). Online: http:www.arts.ualberta .ca/JHS/.

Muecke, The Compass of Irony, 67. 
Praise in order to blame is particularly evident in 14:17 where the woman of Tekoa says, המלך לשמע הטוב והרע Anderson argues that the terms "good and evil" may be a merismus which refers to all of the law. In this case, the use of the term merismus would suggest that David is an exceptional administrator of justice. ${ }^{34}$ Cartledge suggests that this verse should not be interpreted as a merismus, but rather as an indication of the king's sound judgement in legal matters. ${ }^{35}$ Either way, the verse must be interpreted as ironic given that the narrative thus far suggests that David is not a good administrator of justice (including God's disapproval (2 Sam. 12:9)). Moreover, the use of flowery language by the woman of Tekoa emphasises the irony and, thereby, serves to heighten the criticism of David. It is a further issue whether or not the woman of Tekoa intends to be ironic rather than merely intending to flatter him. At any rate, what is evident is the presence of an ironist in the form of an authorial persona. Therefore, this is an instance of impersonal irony and the sub-category is praise in order to blame; more specifically, praise for desirable qualities known to be lacking.

The content of the irony is that David is not a good administrator of justice and, of course, David is the object of ironic attack. This has been a common theme of criticism throughout the SN. The irony is heightened by the woman's remark in 14:17 ויהוה אלהיך יהי עמך given that it is spoken at a stage in the narrative when Yahweh has begun to punish David. ${ }^{37}$

\subsubsection{Samuel 14:18-2o}

At the lower level of 14:18 David asks the woman of Tekoa to be truthful to him, and the woman agrees. In 14:19 David asks the woman if Joab is responsible for the ruse, and the woman replies that Joab is responsible for the ruse and that Joab told the woman what to say. At the lower level of 14:20 the woman tells David that Joab wanted to change the course of events. She also says that David is wise and all knowing. At the upper level of the narrative the ironist implies that David is, in fact, not wise and all knowing. The opposition in the narrative is the difference between what is said and what is known of David, i.e. that he is not wise and all knowing. David is the object of the ironic attack and probably the unknowing victim of the irony.

"The king understands good and evil."

34 Anderson, $W B C$, Vol. 11. 2 Samuel, 189.

35 Cartledge, sнвс. 1 \& 2 Samuel, 550. Cartledge argues that this verse points to the Israelite theology of Kingship, which imagined the king as semi-divine.

36 "And may the Lord your God be with you." Translation from NKJ.

37 Polzin, David and the Deuteronomist. A Literary Study of the Deuteronomic History, 141. 
The grade of verbal irony is covert as it is not immediately apparent. The mode of irony is impersonal irony and the sub-category is praise in order to blame.

In 14:20 this praising in order to blame continues on from 14:17. The woman says,

ואדני חכם כחכםת מלאך האלהים לדעת את־כל־אר בארץ (... my lord has the wisdom of the Angel of God; he knows everything that happens on earth). ${ }^{38}$

However, the content in 14:20 is different from 14:17, as this verse is not specifically concerned with David's ability (or rather, the lack thereof) to administer justice, but rather with his wisdom and knowledge (or rather, the lack thereof). The content of the irony is that David is not wise and all-knowing. As Hugh Pyper suggests, "It is hard to avoid the conclusion that this is ironic when she has just succeeded in hoodwinking him into recalling Absalom. Even his apparent astuteness in identifying the hand of Joab in her intervention comes too late to prevent him from swearing the oath that traps him."39

\subsubsection{Samuel 14:21-23}

At the lower level of 14:21 David allows Absalom to return from exile. In 14:22 Joab prostrates himself in front of David, does obeisance to David, blesses the king, and tells David that he has found favour in the sight of David as his request has been granted. At the lower level of 14:23 Joab goes to Geshur and brings Absalom back to Jerusalem. At the upper level of the narrative the ironist implies that although David has granted Absalom's return, Joab has not found favour with David. The opposition in the narrative can be found in the difference between what Joab explicitly says (that Absalom's return is because Joab has found favour with David) and the implied truth of the situation (that Absalom's return is due to Joab tricking David into swearing an oath).

The grade of verbal irony is covert, as it is not immediately apparent, and the mode of verbal irony is impersonal. The sub-category of verbal irony in these verses is praise in order to blame. However, the previous instances of this sub-category were cases of praise for desirable qualities known to be lacking, whereas this instance of this sub-category is, 'Inappropriate or Irrelevant

38 Translation from NJB.

39 Pyper, "The Enticement to Re-read: Repetition as Parody in 2 Samuel," 159. 
Praise. ${ }^{40}$ The irrelevant praise is expressed in Joab's response to the king in 14:22,

היום ידע עבדך כ־מצאתי חן בעיניך אדני המלך אשר־עשה המלך את־דר עבדו (Today your servant knows that I have found favor in your sight, my lord the king, in that the king has granted the request of his servant). ${ }^{41}$

This praise is patently irrelevant as Joab did not gain the king's favour. Instead David was tricked into making an oath, and David had no option but to follow Joab's plan. Therefore, there is no basis whatsoever in the praise. The content of the irony is that David has been tricked into permitting Absalom to return. David is the object of ironic attack since he has been tricked by a subordinate who now makes him look foolish by praising him

\subsubsection{Samuel 14:24}

Verse 14:24 is not obviously ironic. Nevertheless, a brief commentary is helpful in relation to instances of irony to be discussed in other verses. In 14:24 David tells Joab to direct Absalom to go to Absalom's house and not to come into the king's presence. Of note, David does not act according to the law by allowing Absalom to return to Jerusalem. Similarly, David does not act according to the oath he swore to the woman of Tekoa, as he does not allow Absalom to participate fully in the community. Fokkelman remarks, "David has not executed the spirit of the oath, merely its letter." 42 Yet, in fairness to David, what was he to do? Absalom's return to Jerusalem indicates that there is no guilt in him. David's oath suggests that he has taken on Absalom's guilt unwittingly (14:13), which may indicate that Absalom's position is restored. However, as has been discussed, it is impossible for Absalom to be righteously restored. As I have noted earlier, the deception of Joab and the woman of Tekoa has left David in an invidious position, not unlike the other deceptions in this narrative.

\subsubsection{Samuel 14:25-26}

At the lower level of 14:25 Absalom is spoken of as being the most beautiful man in Israel and without any physical blemishes. At the lower level of 14:26 there is a description of Absalom's hair, which is said to grow very heavy on him, requiring it to be cut annually. At the upper level of the narrative the ironist insinuates that Absalom could potentially try to usurp the throne. This

$40 \quad$ Muecke, The Compass of Irony, 67.

41 Translation from RSv.

42 Fokkelman,"King David (II Sam. 9-20 \& I Kgs. 1-2)," 147. 
insinuation is conveyed in the excessive mention of Absalom's beauty, and in the reference to his plentiful hair. ${ }^{43}$ The incongruity in the narrative concerns the difference between what is said and what is meant. Although the ironist stresses Absalom's physical attractiveness, a quality associated with kings, the ironist is really trying to convey that Absalom is a threat to David. Absalom is the object of the ironic attack.

The grade of verbal irony is covert as it is not immediately apparent. The mode of verbal irony is impersonal and the sub-category of impersonal irony in this instance is a combination of an overstatement and an insinuation. The overstatement is evident in the excessive description of Absalom's physical appearance, which begins in 14:25:

וכאבשלום לא־היה אש־יפה בכל־ישראל להלל מאד (In all Israel there was no one more praised for his beauty than Absalom). ${ }^{44}$

This praise of Absalom, although relevant in the context, is clearly overstated, as 14:25 goes on to state that Absalom was without blemish from the crown of his head to the sole of his foot. In 14:26 the excessive description of Absalom's physical appearance is extended to include a detailed description of Absalom's hair, which was cut and weighed yearly. The overstatement here concerns the weight of Absalom's hair. It was cut annually and weighed and found to weigh

43 It has been suggested that Absalom's act of shaving his hair indicates that he is a temporary Nazarite. If this is true, it may be the case that Absalom had become a temporary Nazarite in order to quiet his 'distemper' (Josephus l.c. http://www.jewishencyclopedia. com/articles/11395-nazarite), which may point to repentance in Absalom. It may also be the case that Absalom is a Nazarite who has dedicated himself as an offering to God. The act of shaving his head each year would be a renewal of his dedication (Eliezer Diamond, "An Israelite Self-Offering in the Priestly Code: A New Perspective on the Nazarite," JQR 88 , no. $1 / 2$ (1997), 1-18, 17-18). It may then be surmised that Absalom took the vow of the Nazarite after ordering the execution of Amnon to do penance. If this is the case then the extreme representation of Absalom's perfection, and the sacrifice of his hair may point to the strength of his remorse. Another consideration is that the emphasis of Absalom's hair points to his pride, which is his sin. This would suggest that Absalom was not holy, but conceited (Gregory Spinner, "Absalom Glorified in His Hair": On the Midrashic Transvaluation of Nazirites.' https://www.academia.edu/6823188/_Absalom_Gloried_in_ His_Hair_On_The_Midrashic_Transvaluation_of_Nazirites). The narrative does not give enough information at this stage for the reader to know if he is remorseful and holy or vain and unholy. However, David Marcus does make the interesting observation that the hair which Absalom is so proud of is ultimately the cause of his undoing.

Translation from NJB. 
in the order of four and a half pounds; but one man's hair could not possibly weigh that much. ${ }^{45}$

The overstatement of Absalom's physical appearance suggests that Absalom had gained great favour in Jerusalem. Bar-Efrat even argues that the mention of Absalom's perfection and luxurious hair is an indicator that fate favoured Absalom. ${ }^{46}$ Indeed, the overstatement may be implying something more than this, namely, that Absalom had the properties of a king. The idea that Absalom had the properties of a king is strengthened when we compare the explicit physical description of Absalom with the explicit descriptions of David and of Saul. In all cases they are extremely flattering, as befits someone about to be anointed king.

Consider, for example, the following description of David just before he is anointed as Saul's successor in 1 Samuel 16:12:

והוא אדמוני עם־יפה עינים וטוב ראי

(Now he was ruddy, and had beautiful eyes, and was handsome). ${ }^{47}$

This description is also comparable to the description of Saul in the story leading up to Saul's anointing (1 Sam. 9:2):

ולו־היה בן ושמו שאול בחור וטוב ואין איש מבני ישראל טוב ממנו משכמו ומעלה גבה מכל־העם

(And he had a son whose name was Saul, a handsome young man. There was not a man among the people of Israel more handsome than he; from his shoulders upwards he was taller than any of the people). ${ }^{48}$

We can conclude from this that those who were about to be anointed as kings were portrayed as being exceptionally physically attractive. Therefore, the overstatement of Absalom's physical attractiveness not only has the implication that he may be next in line to be the anointed king, but also potentially generates the insinuation that Absalom was seeking to take the throne from David.

\subsubsection{Samuel 14:27}

At the lower level of 14:27 it is reported that Absalom had three sons, and a beautiful daughter named Tamar. At the lower level of the narrative the ironist

45 Hertzberg, I \& II Samuel, 334.

46 Bar-Efrat, Narrative Art in the Bible, 50.

47 Translation from Rsv.

48 Translation from RSv. 
does not mention the sons' names but does mention Tamar's name. This is anomalous as it would be expected that, if anything, Absalom's son's names would be mentioned rather than that of the name of his daughter. The opposition in the narrative is the difference between what is said, and what is meant. At the lower level there is a report of Absalom's children, at the upper level of the narrative there is the anomalous stress on Tamar's name. This anomalous stress alludes to Tamar, Absalom's sister, and by extension her rape, and the aftermath of the rape. Here the author as ironist is feigning ignorance of the allusion. As such, the author is an apparent unknowing victim of irony. Yet since the author is only pretending to be unaware of the irony — having intentionally created it - the author is merely a faux-victim of the irony. If this was not a case of dissimulation by the author it would be assumed that either the stress would be on the children equally or there would be more stress on the boys. The object of the ironic attack is Absalom, who is consumed with thoughts of vengeance.

The grade of verbal irony is covert as it is conveyed by means of the language and our background knowledge. As already mentioned, the verbal irony is communicated by the pointed reference to Tamar (his daughter), and the additional mention of Tamar (his daughter) as a אשה יפת.49 This alludes to Absalom's sister, Tamar, who is also described as being beautiful (13:1). Yet, the greater anomaly is in the listing of Absalom's children; as mentioned, Absalom's sons are not referred to by name, however, his daughter is named. Caspari suggests that the attention given to details about Absalom's daughter is particularly suspicious, as elsewhere her name is Maacah (1 Kgs. 15:2). He writes, "... one therefore gains the impression that it pleased the narrator to name the daughter after the avenged sister; this would have been a moment when his predilection for conclusions rich in affinities and ideas sent him beyond what the official documents said." 50

However, this matter requires further discussion. Hertzberg suggests that the mention of Absalom's daughter does not involve an allusion to his sister, and that a more plausible explanation for Absalom's sons not being mentioned by name is it is likely that they died young. For Hertzberg, the mention of Tamar as Absalom's daughter is highlighted because she is his only remaining child. ${ }^{51}$ Ackroyd argues that the text may be confused, and the truth may have been that Amnon raped Absalom's daughter, rather than his sister. ${ }^{52}$ On the other hand

49 "A beautiful woman".

$5^{0} \quad$ Caspari, "The Literary Type and Historical Value of 2 Samuel 15-20," 62.

$5^{1} \quad$ Hertzberg, I \& II Samuel, 334.

52 Peter Ackroyd, The Second Book of Samuel (Cambridge: Cambridge University Press, 1977). 
McCarter suggests that the extended mention of Tamar, Absalom's daughter, is an allusion to Tamar, Absalom's sister. ${ }^{53}$ It would seem that McCarter's proposition is the most plausible. It is possible that Absalom's sons had died young as Hertzberg argues, however, this does not explain the anomaly that Absalom's daughter is named as Tamar and not Maacah, in this instance. Similarly, there is an inconsistency in Ackroyd's interpretation as Tamar is continually referenced as Absalom's sister in the story of Amnon and Tamar. It is more likely, in keeping with the portrayal of Absalom, that the mention of Tamar, his daughter, is best understood as an allusion to his sister, Tamar.

Absalom's anger over Tamar's rape (13:22) precedes verse 14:27 and this, taken in conjunction with the allusion to Tamar (his sister), implies that Absalom's anger has not abated, presumably at least in part because the situation has not been resolved. ${ }^{54}$ The mode of verbal irony is impersonal irony, and the subcategory is innuendo.

\subsubsection{Samuel 14:28-3o}

At the lower level of 14:28 it is reported that Absalom lived for two years in Jerusalem without visiting his father. In 14:29 Absalom sends twice for Joab so that Joab might arrange for Absalom to go to David but Joab does not come. At the lower level of 14:30 Absalom orders his servants to burn Joab's property which is next door to Absalom's property. The opposition in the narrative concerns these different representations of Absalom. Specifically, there is a close confrontation of incompatibles. In 14:28-29 Absalom sends for Joab in a civilized manner. In 14:30, by contrast, Absalom is shown to be as violent and uncompromising as David is. Absalom is the object of ironic attack. The grade of verbal irony is covert as it is not immediately apparent. The mode of verbal irony is impersonal irony, with the dominant sub-category of irony displayed.

At first glance Absalom's decision to light a fire in the field next to his own field is comical, as he is presumably putting himself in danger. However, the confrontation of incompatibles implies that the real focus of this passage is Absalom's anger, as opposed to his foolishness. Fokkelman suggests that this act of arson on Absalom's account points to his aggression. ${ }^{55}$ Similarly Alter remarks, "Absalom's Samson-like burning of the field is a strong indication that he is a man prepared to use violence to achieve his ends: Mafia style, he

53 McCarter Jr., II Samuel, 350.

54 It has been suggested Absalom ordered Amnon's execution as he sought the throne (Hertzberg, I \& II Samuel, 331), however, it is more prudent to assume that Absalom sought revenge against Amnon.

Fokkelman,"King David (II Sam. 9-20 \& I Kgs. 1-2)," 150. 
presents Joab with an offer he can't refuse. ${ }^{\prime 56}$ Caspari suggests that Absalom's failing in this case is 'intransigence. 57

Absalom's behaviour is not unlike David's behaviour toward Uriah. Uriah resists David's two attempts to manipulate him (2 Sam. 11:8; 13) and in frustration David implements the violent plan on the third attempt (2 Sam. 11:14-15) ${ }^{58}$ Therefore, it may be argued that the ironist at the upper level of the narrative is critical of Absalom's scheming and violent behaviour which is not unlike David's modus operandi (2 Sam. 11:6-15). Accordingly, just as the narrative implies that David and Amnon are indistinguishable from one another in terms of their bad character (2 Sam. 11:6-15, 13:1-14), so too does it imply that Absalom is as morally flawed as David and Amnon (14:28-32). Ultimately, therefore the content of the irony is corruption in the monarchy.

\subsubsection{Samuel 14:31-32}

At the lower level of 14:31 Joab goes to Absalom and asks him why he has set Joab's field on fire. At the lower level of 14:32 Absalom replies to Joab that he sent for Joab so that Joab may send a message to the king. Absalom tells Joab to ask the king why Absalom has come from Geshur. Absalom then tells Joab to tell the king that Absalom would have been better off living in Geshur than at a distance from the king, and that if there is any guilt in Absalom then David should kill him. At the upper level of the narrative the question to the king with respect to Absalom leaving Geshur is a rhetorical question, and, as such, ironic. The opposition here is the difference between what Absalom says and what Absalom means. Absalom's question explicitly asks why he has come from Geshur, however, he implies that he wants to know why David has not permitted him to participate fully in the community. David is the object of ironic attack as the ironist, Absalom, implicitly makes a pejorative criticism of David.

The grade of the verbal irony is overt as it is immediately apprehended that Absalom is asking a rhetorical question with an implicit criticism of David. The mode of the irony is impersonal irony and the sub-category, as mentioned previously, is the rhetorical question. However, there are two questions asked. The other question is asked by Joab; Joab asks Absalom why he set Joab's field on fire. This is merely an inquiry, it is not a rhetorical question. By contrast, the

56 Alter, The David Story: A Translation with Commentary of 1 and 2 Sam, 281.

57 Caspari, "The Literary Type and Historical Value of 2 Samuel 15-20," 72.

$5^{8}$ Schulz, 152. 
other question, Absalom's question for David (14:32) is a rhetorical question. This question is:

למה באתי מגשור

(Why have I come from Geshur? $)^{59}$

As we have seen, Absalom is not intending that Joab ask David why Absalom came from Geshur since this is already known to both Absalom and David. This rhetorical question is an element of Absalom's speech to Joab expressing his anger that his predicament has not been resolved by David.

However, there is an additional implication, namely, that there is no easy answer to Absalom's predicament. As has been discussed, the proper course of action for David to take in response to Absalom's unlawful act of killing Amnon, was to have Absalom killed, ${ }^{60}$ or to leave Absalom in exile (in keeping with the story of Cain and Abel). In ordinary circumstances there would be guilt in Absalom. Thus, Absalom's remark in 14:32 is as follows:

ועתה אראה פני המלך ואם־יש־בי עון והמתני

(Now therefore let me go into the presence of the king; and if there is guilt in me, let him kill me) ${ }^{61}$

Given the outcome of the ruse of the woman of Tekoa, David has sworn to take on Absalom's guilt, and thereby, David himself, rather than Absalom, should rightly be killed (or, at least, exiled). Therefore, there is no easy solution to Absalom's predicament.

\subsubsection{Samuel 14:33}

Identifying irony in 14:33 is difficult, and it is likely that this verse is a straightforward narration of events. However, there is also a possibility that irony arises from the understatement of David's act of kissing Absalom. If there is irony perhaps it is as follows.

At the lower level of 14:33 Joab goes to the king and tells him what Absalom told him to tell David. David summons Absalom, and Absalom comes to David and prostrates himself before David. David then kisses Absalom (14:32). At

\footnotetext{
59 Translation from NRs.

6o In 14:32 Absalom's remark, "Let him kill me" supports the idea that death is an appropriate punishment for Absalom killing Amnon.

61 Translation from RSv.
} 
the upper level of the narrative the ironist emphasises the significance of this event by using understated language. Moreover, the significance of the event is otherwise indicated. After all, restoring Absalom is contrary to the laws and even, it would appear, to Absalom's expectation of his own treatment!

The grade of verbal irony is covert as it is conveyed in the language and by recourse to background knowledge. As far as the understated language is concerned, Schulz notes that 14:33 is the climax of chapter 14, yet he also notes that Absalom's reconciliation with David is described fleetingly. ${ }^{62}$ However, regardless of the understated representation of this event, it might also be added that the wording is to some extent belaboured. In this respect Perry and Sternberg's pattern of verbosity and curt expression is helpful. The verbosity is evident in 14:33a, and the curt expression is in 14:33b. The curt expression is as follows:

(And the king kissed Absalom).

וישק המלך לאבשלום

David's kiss has variously been interpreted to mean that Absalom had been restored to favour, ${ }^{63}$ that Absalom was kissed in order to seal his place as the future king, ${ }^{64}$ and that the kiss was a simple greeting gesture as can be seen in Genesis 33:4; 50:1; Exodus 18:7.65 However, given that the entire chapter has been concerned with the appropriate treatment of Absalom, it is reasonable to interpret the kiss as restoring Absalom to favour. This is in keeping with Bar-Efrat's suggestion that the mention of מלך three times in this verse, emphasizes an official atmosphere, and is otherwise devoid of the personal warmth that may be expected of the reunion of a father and son. ${ }^{67}$

The complexity in respect of Absalom's restoration has been handled by David in an injudicious manner, as was the manner in which David chose to deal with the situation of Uriah and Bathsheba. ${ }^{68}$ The criticism in this regard, then, is that David has unrightfully restored Absalom as the heir to the throne, and even though in doing so David has been true to his oath, nevertheless, it has been brought about only through trickery. This does not portray a king who

62 Schulz, "Narrative Art in the Books of Samuel," 124.

63 Conroy, Absalom! 103.

64 Schulz, "Narrative Art in the Books of Samuel," 124.

65 Anderson, WBC, Vol. 11. 2 Samuel, 191.

66 "king"

67 Bar-Efrat, Narrative Art in the Bible, 157.

68 Hertzberg, I \& II Samuel, 335. 
administers justice adequately for the good of the community. The content of the irony is David's inability of administer justice effectively and David is the object of ironic attack. An additional irony is supplied by Marcus who suggests that it is ironic that David kisses Absalom as a sign of restoration given that Absalom later (2 Sam. 15:5) uses kisses as a means of gaining support for his revolution. ${ }^{69}$

\subsubsection{Summary of 2 Samuel 14:1-33}

This chapter is full of characters who act deceptively or otherwise immorally or unlawfully. Joab tricks David into swearing an oath that David does not want to uphold. The woman of Tekoa is the agent of Joab's deception. Even the fictitious blood-avenger is motivated by inheritance. David upholds the oath that he is held to, however, he appears to do it begrudgingly, and Absalom can be accused of being deceptive when he tricks Joab into championing him further to David. The ironic criticism in the text might then concern the matrix of corruption, as opposed to obedience to Yahweh, which comes through in this narrative.

In $14: 1-3$ there is an insinuation that Joab's plan is deceptive. $14: 4-7$ is an example of the sub-category of impersonal irony, pretended defence of the victim, where David's incompetence is 'defended'. 14:8-11 is an example of overstatement. In this instance, David, who is the victim of the irony, is tricked into taking an oath which absolves Absalom of any punishment for Amnon's death. 14:12-14 uses a rhetorical question to highlight the oath which David has taken on. In 14:15-17, the sub-category of irony called praise in order to blame, suggests that David is not a good administrator of justice.

In 14:18-20 the sub-category of praise in order to blame highlights the fact that David does not know what is going on around him. In 14:21-23 irrelevant praise is given by Joab. This falls under the sub-category of irony, praise in order to blame. Joab thanks David for his favour, despite knowing that he tricked David. In 14:25-26 Absalom's perfection is overstated. This leads into an insinuation that Absalom is planning to take the throne. In 14:27 there is an innuendo which comes with the mention of Absalom's daughter, Tamar. 14:28-30 is an example of irony displayed, which points to Absalom's aggression. In 14:31-32 a rhetorical question elucidates the confusion of the narrative by suggesting that Absalom should not have left Geshur, and that David has not successfully administered justice in this instance. 14:33 closes the chapter

$69 \quad$ I am indebted to David Marcus for this comment. 


\section{with understated language which points to an unresolved reconciliation be- tween Absalom and David. ${ }^{70}$}

70 At this stage in the narrative it is worth noting the parallels between the story of Saul's demise and the present story of King David. In doing so, the reader becomes aware that David is failing as a king in this narrative, from the perspective of a parallel narrative. In 1 Samuel 14:1 Jonathan does not tell Saul that he is fighting with the Philistines, just as Absalom kept his intentions regarding Amnon a secret (13:23-27). Saul commits himself to a rash oath which ends up having implications for his son (1 Sam. 14:24). Similarly, David is tricked into committing to an oath which involves his son (14:10-11). Jonathan does not know of Saul's oath (1 Sam. 14:27), just as Absalom did not know of David's oath (14:32). Jonathan rebels against his father's oath (1 Sam. 14:29), Absalom rebels against David's decision (14:32). Saul builds the first altar to the Yahweh (1 Sam. 14:35), David wants to build the first temple to the Yahweh (2 Sam. 7:2). God does not answer Saul (1 Sam. 37), just as God does not respond to David's fasting (2 Sam. 12:22-23). God discerned that guilt was in Saul and Jonathan, but not in the people (1 Sam. 14:41), similarly, the guilt in Absalom is reputed to have been transferred to David (2 Sam. 14:9). In 1 Samuel 14:44 Saul attempts to take on Jonathan's guilt. The people of Israel rescued Jonathan from God's judgement so that not one hair should fall onto the ground (1 Sam. 14:45), David ensures that not one of Absalom's hairs should fall to the ground (2 Sam. 14:11). In 1 Samuel 15:9 Saul takes the spoils of war, and in 2 Samuel 12:30 David takes the spoils of war. Saul is rejected in 1 Samuel 15:10, and David is rejected in 2 Samuel 12:24-25. Saul did evil in the sight of the Lord (1 Sam. 15:19), as David did evil in the sight of the Lord (2 Sam. 12:9). Saul recognises that he has sinned in the eyes of God (1 Sam. 15:24), just as David did (2 Sam. 12:13). Saul's sin leads to his rejection (1 Sam. 15:26), and into the narrative of the anointing of David in 1 Samuel 16. 